\title{
What Rules, if not Customary International Law - Articles 31-32 of the VCLT - Are the U.S. Courts Relying upon while Applying and Interpreting Tax Treaty Provisions?
}

\author{
Dalton Luiz Dallazem \\ University of Florida, Gainesville, U.S., dallazem@ufl.edu
}

\begin{abstract}
The Vienna Convention on the Law of Treaties (VCLT) contemplates the interpretation of treaties topic in its articles 31, 32 and 33, portraying the frame to be followed by one who is engaged in this difficult endeavor. Tax treaties are, fore and foremost, treaties. Therefore, the VCLT is the leading guideline for their interpretation. The United States has sixty-eight income tax treaties in force. If one logs on any website provider of case-law services and types "tax treaty," more than six hundred cases will pop up. This paper focuses both on what courts have been doing and on what they could have been doing, according to the VCLT, when ruling about tax treaties, but theorizing an approach to the interpretation of tax treaties is not its intent. Regardless of the inference of Savigny and other jurists that "interpretation is an art" and "cannot be learned and governed by any specific rules," in accordance with the preponderant point of view, customary international law has developed rules on interpretation of treaties, which are accurately contemplated in the VCLT. Still, the American judiciary does not exactly follow its rules. Nonetheless, the U.S. court decisions that have already applied the interpretation rules of the VCLT are "especially valuable" as substantiation of international law since they are rendered by courts of a nation not a party to the Convention, and their importance is further reinforced because the United States, as the most active treaty-maker in the world, decidedly influences the law applicable to treaties.
\end{abstract}

KEYWORDS: customary international law, interpretation, tax, treaties, United States courts, Vienna Convention on the law of treaties

\section{Introduction}

\begin{abstract}
"[W]here there is no treaty, and no controlling executive or legislative act or judicial decision, resort must be had to the customs and usages of civilized nations; and, as evidence of these, to the works of jurists and commentators, who by years of labor, research and experience, have made themselves peculiarly well acquainted with the subjects of which they treat." [Mr. Justice Gray, delivering the opinion of the Supreme Court in The Paquete Habana, 175 U.S. 677 (1900)].
\end{abstract}

In the summer of 2004, Avi-Yonah made a point that it would be a good idea for international tax lawyers to study the Vienna Convention on the Law of Treaties. He mentioned the case of Xerox Corporation $v$. United States, one of the cases analyzed by this paper, to imply a different result under the interpretive principles enshrined in the articles 31-33 of the Convention (Avi-Yonah 2004, 491-493).

The United States has sixty-eight income tax treaties in force. If one logs on any website provider of case law services and types "tax treaty interpretation," more than six hundred cases will appear. However, there is only one case citing expressly the interpretive principles of the VCLT (Coplin v. United States), which is understandable since it has not yet received U.S. Senate advice and consent to ratification. The Supreme Court has only cited to it twice, and an in incidental fashion, but the cases are not about tax treaties (Kysar 2016, 1402).

The decisions adjudicated by the U.S. courts do not portray a uniform approach to the interpretation of tax treaties. A considerable assorted of them highlight the interaction differently among the treaty text, the purpose of the treaty, the goal of the negotiators, the Senate opinion and what are the appropriate resources to the analysis of all these factors.

This paper focuses both on what courts have been doing and on what they could have been doing when ruling on tax treaties. Theorizing an approach to the interpretation of tax treaties, however, is not its intent. Instead, its purpose is to demonstrate the feasibility and importance of the VCLT for the subject, summoning the courts to apply its interpretive principles. 
Regardless of the inference of Savigny and other jurists that "interpretation is an art" and "cannot be learned and governed by any specific rules," following the preponderant point of view, customary international law has developed rules on interpretation of treaties, which are accurately contemplated in the Vienna Convention (Frankowska 1988, 327-328). Still, the American judiciary does not precisely follow its rules (Kysar 2016, 1408).

Nonetheless, the U.S. court decisions that have already applied the interpretation rules of the VCLT the vast majority of them out of the arena of tax treaties - are "especially valuable" as substantiation of international law since they are rendered by courts of a nation not a party to the Convention, and their importance is further reinforced because the United States, as the most active treaty-maker in the world, decidedly influences the law applicable to treaties (Frankowska 1988, 384-385).

\section{The Articles 31-32 of the Vienna Convention on the Law of Treaties and Their Status of Customary International Law in the United States}

"The treaty on treaties" (Kearney and Dalton 1970, 495), "[t] he Bible of the international lawyer" (AviYonah 2004, 483), the "[t]reaty designed to govern all other treaties" (Frankowska 1988, 285), or "a giant step for mankind toward a world in which the rule of law will be not a dream but a reality" (Kearney and Dalton 1970, 561), the VCLT "[h] as the potential to be the international instrument most often relied upon by national courts" (Frankowska 1988, 286).

In line with a ubiquitous opinion juris of the international community, the VCLT portrays a treaty which to a large extension is a restatement of customary law, binding States independently they are parties to the Convention or not. Even before the VCLT entered into force, States and the International Court of Justice had been invoked its provisions (Frankowska 1988, 286). Regarded as being amid the most successful provisions of the VCLT, it is said articles 31-33 attain a characteristic and fortunate balance between sobriety, flexibility, and normative guidelines. They are among those articles regarded as expressive of customary international law (Kolb 2006, 128).

If one visits the U.S. Department of State website and searches for the VCLT, the first information he or she will see is that transcribed below:

Is the United States a party to the Vienna Convention on the Law of Treaties?

No. The United States signed the treaty on April 24, 1970. The U.S. Senate has not given its advice and consent to the treaty. The United States considers many of the provisions of the Vienna Convention on the Law of Treaties to constitute customary international law on the law of treaties.

In the first two decades after the signing of the VCLT, fourteen cases in the United States invoked its provisions, seven of which concerned with the interpretation of treaties. All of those decisions were rendered by federal courts and all seven concerned with interpretation invoked article 31, the "general rule of interpretation" (Frankowska 1988, 307-308). The courts avoided the intricate problem of identifying customary international law, using the Vienna Convention as a convenient anchorage. Nonetheless, for the courts of the United States - and of any State not a party to a treaty - the burden of determining the content of customary international law is not affected by the existence of a purportedly systemic treaty (Frankowska 1988, 387-388).

After that first two decades, we can also observe federal and state courts resorting to the VCLT interpretative rules, but now they have accomplished the task of distinguishing standards of customary international law (Kysar 2016, 1402). As Criddle identified, "many lower federal and state courts apply the Convention's treaty-interpretation provisions routinely as customary international law" (Criddle 2004, 434).

The debate about the status of customary international law in U.S. courts has been vigorous over the past two decades (Born 2017, 1641). Nonetheless, there is no doubt that articles 31 and 32 of the VCLT are considered by the United States as such (Brief for the United States as Amicus Curiae Supporting Petitioner, Abbott v. Abbott).

In this perspective, the 2017 Annual Meeting of The American Law Institute Council approved the language of Section 106, Chapter 2, of the Restatement of the Law Fourth, The Foreign Relations Law of the United States Treaties. The text reproduces what is expressed in the articles 31 and 32 of the VCLT. 
The introductory Reporters' Memorandum to the Section 106 language stated:

\begin{abstract}
"The prior Restatement did not recognize the Vienna Convention Articles 31 and 32 as fully reflecting customary international law regarding the rules for treaty interpretation and identified some potential divergence between the U.S. approach to interpretation of treaties and that of the Vienna Convention. However, subsequent developments in international law and state practice in applying the Vienna Convention principles, and in the U.S. domestic approach to interpretation of treaties, have both solidified international acceptance of the Vienna Convention standard and narrowed any perceived divergence in approach."
\end{abstract}

The new Section 106 incorporates the principles of the articles 31 and 32 of the VCLT. The deference to the executive expressed in its paragraph 6 ought not to be understood as an authorization for the adoption of a unilateral interpretation. Indeed, the Reporters' notes explanation of this topic resort to Sumitomo, and in this case, the Supreme Court sustained the meaning as the "[m]eaning attributed to treaty provisions by the Government agencies" (Sumitomo, 184-185). In addition, the Court stated, "when the parties to a treaty both agree as to the meaning of a treaty provision, and that interpretation follows from the clear treaty language, we must, absent extraordinary strong contrary evidence, defer to that interpretation" (Sumitomo, 185). Well, "Government agencies" and "the parties to a treaty" are interpretation agreed to by the parties, not unilateral.

\title{
Tax Treaties Cases and the VCLT
}

\section{A. Xerox Corporation v. United States}

Xerox brought an action to recover federal income taxes paid for its taxable year ended December 31, 1974. The U.S. Claims Court held that United States corporate taxpayer was not entitled to foreign tax credit for portions of British subsidiary's (Rank Xerox, Limited - RXL) "advance corporation tax" (hereinafter "ACT") which subsidiary (RXL), in turn, had surrendered to its British subsidiaries, according to the British law.

The issue before the Court was whether the surrender by RXL of a portion of its ACT (the portion used to offset RXL mainstream corporation tax was not in dispute) to U.K. subsidiaries should have any effect on the availability of an Article 23(1)(c) U.S. foreign tax credit to its parent, Xerox (the article cited is from the Convention for the Avoidance of Double Taxation and the Prevention of Fiscal Evasion with Respect to Taxes on Income, U.S.-U.K).

The Claims Court refused the tax credit right claimed by Xerox centered on the ensuing grounds: (a) the language of the treaty itself; (b) the synchronous technical explanation; (c) the Revenue Procedure 80-18, and (d) a competent authority agreement.

Examining the case, the Claims Court concluded that the article 23(1)(c) cannot be interpreted without consideration to the article 23(1), which says: "[i]n the case of a United States corporation owning at least 10 per cent of the voting stock of a corporation which is a resident of the United Kingdom from which it receives dividends in any taxable year, the United States shall allow credit for the appropriate amount of tax paid to the United Kingdom by that corporation with respect to the profits out of which such dividends are paid". (Emphasis added).

Indeed, the portion of the ACT surrendered to a subsidiary is not a tax paid "by the United Kingdom Corporation" that distributed the dividends. Consequently, it is correct to conclude that the U.S.-U.K. Tax Treaty language warrants the tax credit unless or until the ACT is set off against mainstream corporation tax in the United Kingdom.

Consequently, after analyzing the text of the convention, the Claims Court was diligent in building the interpretation based on other elements - the technical explanation; the Revenue Procedure 80-18, and a competent authority agreement - but only after interpreting the text of the treaty itself. Therefore, without citing it, the Claims Court applied Article 32 of the VCLT correctly, resorting to supplementary means of interpretation to confirm the meaning resulting from the application of article 31 .

Conversely, the Court of Appeals concluded that it was necessary to look at the intention of the parties and reversed. It relied on affidavits of treaty negotiators not even synchronous with the treaty but executed years later when the affiants were in private practice and had no risk in safeguarding the Treasury. The affidavits could fit, at best, on article 32 of the VCLT, therefore inferior sources of those employed by the Claims Court - Article 31 (Avi-Yonah 2004, 493). However, according to the VCLT, little or no weight 
should generally be given to evidence of individual treaty negotiators in the interpretation of a tax treaty. In a clear nationalist approach to the interpretation of the treaty, the Court of Appeals looked outside the text and the context, not even using the supplementary materials mentioned in the article 32 of the VCLT.

In conclusion, if the Court of Appeals observed the VCLT, much probably the Claims Court decision would be upheld, and no tax credit would be allowed. As stated by Avi-Yonah, the consensus is that Xerox "got away with murder" (Avi-Yonah 2004, 493).

\section{B. Coplin v. United States}

Taxpayers, all United States citizens, during the respective relevant tax years were employees of the Panama Canal Commission (Commission), an agency of the United States government. The wages they received from the Commission were included in computing their federal income tax for the years 1979, 1980, and 1981. Based on their understanding of an international agreement, the taxpayers filed claims for refund for the amount of tax paid concerning income received from the Commission. The Internal Revenue Service denied each of their claims and these suits followed.

On September 7, 1977, after years of negotiation, the United States and the Republic of Panama signed the Panama Canal Treaty. The Senate approved the treaty, and it entered into force on October 1, 1979, restoring to Panama territorial sovereignty over the Canal Zone. Panama granted to the United States the right to manage, operate, and maintain the canal until the year 2000. During this period the canal was to be operated by the Commission.

Because the Canal Zone would no longer be subject to United States territorial sovereignty, it was necessary to define the rights and legal status of the Commission and its employees vis-a-vis each country. These matters were to be governed by the Agreement Implementing Article III of the Panama Canal Treaty (Implementation Agreement), whose Article XV deals with taxation of the Commission and its United States citizen employees:

\section{ARTICLE XV}

Taxation

1. By virtue of this Agreement, the Commission, its contractors and subcontractors are exempt from payment in the Republic of Panama of all taxes, fees or other charges on their activities or property.

2. United States citizen employees and dependents shall be exempt from any taxes, fees, or other charges on income received as a result of their work for the Commission. Similarly, they shall be exempt from payment of taxes, fees or other charges on income derived from sources outside the Republic of Panama.

The dispute centers on the correct interpretation of the first sentence in paragraph two. The taxpayers claimed that, according to a literal interpretation, income earned by all United States citizens from the Commission was exempt from United States income taxation. The government contended that the provision was intended to bar only Panama, and not the United States, from taxing Commission employees.

In the Claims Court, the government argued that the treaty language should not be construed literally because to do so would violate the intention of the signatories. The court recognized that it should not give literal effect to treaty language if it were persuaded that such language did not reflect the intention of the parties. The court observed that "the record is devoid of any statement of the official Panamanian position." Despite government arguments that the literal language did not reflect the intention of the United States, the court construed the language literally because the government presented "no evidence whatsoever as to the interpretation given this language by Panama."

The articles of the VCLT dealing with interpretation are expressed mentioned by the Claims Court in two passages:

In construing treaties, words "are to be taken in their ordinary meaning ... and not in any artificial or special sense impressed upon them by local law." Geofroy v. Riggs, 133 U.S. at 271, 10 S.Ct. at 298; accord Santovincenzo, 284 U.S. at 40, 52 S.Ct. at 84; see Vienna Convention art. 31, 63 Am.J.Int'1 L. 885.

Finally, defendant argues that the United States Senate treaty language should not be construed in accordance with its plain meaning because to do so would do violence to the intention of the signatories. A court ought not, of course, give literal effect to treaty language if it is persuaded that such language does not reflect the intention of the high contracting parties. See, e.g., Sumitomo Shoji, 457 U.S. at 180, 102 S.Ct. at 2377; Great- West Life Assurance Co.v. 
United States, 678 F.2d 180, 230 Ct.Cl. 477, 481 (1982); Vienna Convention art. 32, 63 Am.J.Int'1 L. 885. On the other hand, the court may not simply rewrite the contract to achieve an end it deems desirable.

On those grounds, the Claims Court granted the refund to the taxpayers.

Nonetheless, when the case was already on the Court of Appeals, it was informed by the government that "[o]n February 25, 1985, the United States received a diplomatic note from the Panamanian Foreign Minister in which he confirmed that the Panamanian Foreign Ministry shared the United States' view that the Implementing Agreement was not intended to affect United States taxation of Commission employees." Letters from the Panamanian team that negotiated the Implementation Agreement were enclosed by the Foreign Minister, where they confirmed that Paragraph 2 of Article XV was "discussed, negotiated and drafted exclusively with respect to the tax exemption that the Republic of Panama would grant to United States-citizen employees of the Commission and their dependents."

Furthermore, according to the negotiators, the "provisions resulted from negotiations that did not deal with the United States authority to tax the individuals mentioned therein." The Court of Appeals also registered that "[I]n an appendix to the brief the government included the cable from the United States embassy in Panama transmitting the diplomatic note and the accompanying letters to the State Department."

The Court of Appeals admitted the new evidence grounded on Supreme Court case law establishing an exception to the general rule when interpreting the meaning of treaties, whose plain words were:

\footnotetext{
The court's "role is limited to giving effect to the intent of the Treaty parties." Sumitomo, 457 U.S. at 185, 102 S.Ct. at 2380; accord Great-Western Life Assurance Co. v. United States, 678 F.2d 180, 183, 230 Ct.Cl. 477 (1982) (treaties must be construed to enforce intent of contracting parties). Because we deny the motions to strike, the record now reveals the intent of each government. Since both treaty parties agree that paragraph 2 was not intended to create an exemption from United States domestic taxation, the trial court's decision cannot be upheld. It is the government, not the taxpayers, which is entitled to judgment as a matter of law. Therefore, we reverse the decision of the Claims Court and direct that summary judgment be granted in favor of the appellant.
}

Now, although not expressly mentioned, the Court of Appeals applied Article 31 in conjunction with article 32 VCLT. Moreover, with all due respect, even though the Claims Court expressess consideration to the Article 31 VCLT, it seems that the "context" of the Implementation Agreement does not authorize its conclusion granting the refund.

In effect, Paragraph 1 of Article XV explicitly grants the exemption "in the Republic of Panama," therefore Paragraph 2 must follow this guidance. Additionally, the second sentence of Paragraph 2 says, "[s]imilarly, they shall be exempt from payment of taxes, fees or other charges on income derived from sources outside the Republic of Panama." Well, if the second sentence states that the U.S. citizens employees are exempt from income earned outside the Republic of Panama, it seems that the first sentence (bone of contention) is affording the exemption "inside" Panama only, not in the United States territory.

Now, when the Court of Appeals - whose work was easier, by the way - decided to admit the evidence, the recourse of article 32 VCLT emerges to "confirm the meaning resulting from the application of article 31 " as the new evidence can be viewed as "preparatory work of the treaty and the circumstances of its conclusion".

\section{O'connor v. United States}

The petitioners were United States citizens and employees of the Panama Canal Commission seeking refunds of income taxes collected on salaries paid by the Commission between 1979 and 1981. The petitioners contend that $\S 2$ of the Article XV of the Agreement signed between the U.S. and Panama for purposes of avoiding the double taxation constitutes an express exemption of their Commission salaries from both Panamanian and United States taxation.

The Supreme Court held in favor of the Government building its arguments from the context and in the light of the object and purpose of the Agreement, according, then, article 31(1) of the VCLT. "[M] ore persuasive than the textual evidence, and in our view overwhelmingly convincing," affirmed the Court, "[i]s the contextual case for limiting Article XV to Panamanian taxes." 
Additionally, the Court took into account together with the context, as the VCLT expresses in article 31(3)(b), a practice in the application of the treaty which established the agreement of the parties regarding its interpretation:

\footnotetext{
It is undisputed that, pursuant to clear Executive Branch policy, the Panama Canal Commission consistently withheld United States income taxes from petitioners and others similarly situated, see Letter from John L. Haines, Jr., Deputy General Counsel, Panama Canal Commission, to David Slacter, United States Department of Justice, Dec. 20, 1982, pp. 2-3, 1 App. in Nos. 85-504, 85-505, 85-506, and 85-507 (CA Fed.), pp. 61-62, and that Panama, which had four of its own nationals on the Board of the Commission, did not object. The course of conduct of parties to an international agreement, like the course of conduct of parties to any contract, is evidence of its meaning.
}

Here is an example, therefore, of the employment of the VCLT by the Supreme Court, although it was not explicitly cited in the verdict of the Court.

\section{Conclusion}

Regardless of different opinions (Kysar 2016, 1387), this paper argues that the courts should resort to the VCLT when ruling about tax treaties. As demonstrated, some of them are already doing it, although not expressly citing it. On the other hand, cases as Xerox $v$. United States demonstrate the inconvenience of not applying the VCLT. The application of the VCLT by the U.S. courts as an encompassment of customary international law on the field of interpretation of tax treaties helps to promote the development of international law within the international legal order. Implicit in those decisions which have already applied the Convention rules of interpretation is the conviction that the United States is bound by them, despite the non-ratification (Frankowska 1988, 383).

In 1984, Dalton stated, "has not the time come for the executive branch and the Senate to look again at the Vienna Convention on the Law of Treaties to assess whether overall U.S. interests would be served by our be coming a party to it?" (Dalton 1984, 279). And in 1988, Frankowska summoned, "[t]he time has come for the Senate to give the Convention serious consideration" (Frankowska 1988, 390).

Finally, as the Reporters' notes to the Section 106 approved language of the Restatement of the Law Fourth indicated:

\footnotetext{
[a]lthough U.S. courts have not always precisely tracked the principles set forth in the Vienna Convention, their approach to treaty interpretation has generally been consistent with those principles. Subsequent developments in international law and state practice in applying the Vienna Convention criteria, as well as in the U.S. domestic approach to interpretation of treaties, have both solidified international acceptance of the Vienna Convention standard and helped to reduce any perceived divergence in approach.
}

Incorporating the customary interpretive standards into U.S. jurisprudence symbolizes a critical step toward the development of a coordinated international system for treaty adjudication (Criddle 2004, 436).

\section{References}

Avi-Yonah, Reuven S. 2004. International Tax as International Law, 57 Tax L. Rev. 483.

Born, Gary. 2017. Customary International Law in United States Courts, 92 Wash. L. Rev. 1641.

Brief for the United States as Amicus Curiae Supporting Petitioner, Abbott v. Abbott, Case n. ${ }^{\circ}$ 08-645 (2010), at 9 and n. 6 (citing Fujitsu Ltd. v. Federal Express Corp., 247 F.3d 423, 433 (2d Cir. 2001)).

Coplin v. United States, 6 Cl.Ct. 115 (1984), and Coplin v. United States, 761 F.2d 688, 691 (1985).

Criddle, Evan. 2004. The Vienna Convention on the Law of Treaties in U.S. Treaty Interpretation, 44 Va. J. Int'l L. $431,434$.

Dalton, Robert E. 1984. The Vienna Convention on the Law of Treaties: Consequences for the United States, 78 Am. Soc'y Int'1 Proc. 279.

Frankowska, Maria. 1988. The Vienna Convention on the Law of Treaties before United States Courts, 28 Va. J. Int'l L. 281, 327-328.

Kearney, Richard D., and Robert E. Dalton. 1970. The Treaty on Treaties, 64 Am. J. Int'1 L. 495.

Kolb, Robert. 2006. The Law of Treaties: An Introduction. Northampton, MA: Edward Elgar Publishing Ltd.

Kysar, Rebecca M., 2016. Interpreting Tax Treaties, Iowa L. Rev. 1387.

O'Connor v. United States, 479 U.S. 27 (1986).

Sumitomo Shoji America, Inc. v. Avagliano, 457 U.S. 176 (1982)

Xerox Corporation v. United States, 14 Cl. Ct. 455 (1988).

Xerox Corporation v. United States, 41 F.3d 647, 656 (1994). 